University of Nebraska - Lincoln

DigitalCommons@University of Nebraska - Lincoln

Peter Dowben Publications

Research Papers in Physics and Astronomy

July 1987

\title{
The stability and decomposition of gaseous chloroferrocenes
}

S. Barfuss

Institut fur Physikalische Chemie, Freie Universitat Berlin, Takustrasse, Berlin, Federal Republic of Germany

M. Grade

Institut fur Physikalische Chemie, Freie Universitat Berlin, Takustrasse, Berlin, Federal Republic of Germany

W. Hirschwalde

Institut fur Physikalische Chemie, Freie Universitat Berlin, Takustrasse, Berlin, Federal Republic of Germany

W. Rosinger

Institut fur Physikalische Chemie, Freie Universitat Berlin, Takustrasse, Berlin, Federal Republic of Germany

N.M. Boag

Syracuse University

See next page for additional authors

Follow this and additional works at: https://digitalcommons.unl.edu/physicsdowben

Part of the Physics Commons

Barfuss, S.; Grade, M.; Hirschwalde, W.; Rosinger, W.; Boag, N.M.; Driscoll, D.C.; and Dowben, Peter A., "The stability and decomposition of gaseous chloroferrocenes" (1987). Peter Dowben Publications. 131.

https://digitalcommons.unl.edu/physicsdowben/131

This Article is brought to you for free and open access by the Research Papers in Physics and Astronomy at DigitalCommons@University of Nebraska - Lincoln. It has been accepted for inclusion in Peter Dowben Publications by an authorized administrator of DigitalCommons@University of Nebraska - Lincoln. 


\section{Authors}

S. Barfuss, M. Grade, W. Hirschwalde, W. Rosinger, N.M. Boag, D.C. Driscoll, and Peter A. Dowben 


\title{
The stability and decomposition of gaseous chloroferrocenes
}

\author{
S. Barfuss, M. Grade, ${ }^{\text {a) }}$ W. Hirschwald, and W. Rosinger \\ Institut fü Physikalische Chemie, Freie Universität Berlin. Takustrasse 3, 1000 Bertin 33. Federal Republic \\ of Germany \\ N. M. Boag, b) D. C. Driscoll, and P. A. Dowben \\ Laboratory for Solid State Science and Technology, Syracuse University, Syracuse, New York 13244-1130
}

(Received 11 August 1986; accepted 20 October 1986)

\begin{abstract}
The ionic and neutral decomposition of gaseous ferrocene, 1, 1'-dichloroferrocene and 1, 1',2, 2'. tetrachloroferrocene, has been investigated via photon and electron induced ionization mass spectroscopy. The thermodynamic cycle incorporating the ionic and neutral fragments of ferrocene has been constructed. Elimination reactions in the decomposition of the dichloroferrocene and tetrachloroferrocenes have been identified.
\end{abstract}

\section{INTRODUCTION}

The decomposition of neutral and ionic gaseous ferrocenes has not been carefully elucidated despite their potential technological importance in organometallic vapor phase epitaxy (OMVPE) ${ }^{1}$ For plasma assisted deposition process, an understanding of the plasma chemistry is crucial to modeling of plasma decomposition and predicting deposition products. In a plasma, positive ions are created from the ambient gas as a result of the impact of electrons into neutral gaseous species. Similar processes resulting in the creation of positive ions occur in the ion source of a mass spectrometer. Electrons incident upon a stream of gaseous molecules will, if imparted with sufficient kinetic energy, create positive ions, which may then be mass selected and detected. For this reason, a mass spectrometer can be used to investigate some of the processes which may occur in a plasma. ${ }^{2}$

In an earlier communication, ${ }^{3}$ the electron structure of gaseous ferrocene and the chloroferrocenes, $\mathrm{Fe}\left(\mathrm{C}_{5} \mathrm{H}_{5-N} \mathrm{Cl}_{N}\right)_{2}(N=0-5)$, was described. Increasing chlorination resulted in increasingly larger ionization potentials and an electron structure consistent with greater stability of the gaseous molecule. In this work, we will discuss the decomposition and stability of chloroferrocene ions from results derived by electron impact mass spectroscopy and photoionization and provide some insight into some of the processes that may occur in plasma assisted deposition employing ferrocenes.

\section{EXPERIMENTAL}

The complexes were prepared as described previously. ${ }^{3}$

The electron impact mass spectroscopy experiments were undertaken using a molecular beam of sample vapor generated in an alumina Knudsen cell. This beam was directed into the ionization region of the electron impact ion source of a Varian MAT single-focusing magnetic field mass spectrometer. Ionization efficiency curves (IEC), i.e., plots of ion intensity versus electron impact energy were recoraed under isothermal vaporization conditions in steps of $0.025 \mathrm{eV}$ between 6 and $25 \mathrm{eV}$ incident electron energy. For details concerning calibration, data reduction, evaluation procedure, and analysis of the fine structure of the IEC's see Refs. 4 and 5.
The alumina Knudsen cell, used as a source for gaseous parent species, was encased in a tantalum mantle. The sample gas was generated from the Knudsen cell which contained equilibrium gas phase above the pure solids at temperatures between 300 and $400 \mathrm{~K}$. A constant temperature in the Knudsen cell was used for each experiment. Many experiments were repeated at different temperatures and different corresponding effusion rates to confirm that results remained independent of pressure.

The fragmentation of 1,1'-dichloroferrocene was also studied by photoionization using synchrotron radiation in a high-temperature photoionization system in the photon energy region $10-24 \mathrm{eV}$. The synchrotron radiation source was the electron storage ring BESSY (Berliner Elektronenspeicherring fuer Synchrotronstrahlung $\mathrm{GmbH}$ ) in Berlin, BRD. The light was dispersed by a Wadsworth monochromator with a 1200 lines $/ \mathrm{cm}$ Al with $\mathrm{MgF}_{2}$ coated parabolic grating and reflecting mirror. The ions were detected using Balzers QMG 311 quadrupole mass spectrometer.

\section{RESULTS}

From the equilibrium vaporization of ferrocene, $\mathrm{Fe}\left(\mathrm{C}_{5} \mathrm{H}_{5}\right)_{2}$, the following parent and fragment species were identified in the mass spectrum $\mathrm{FeC}_{10} \mathrm{H}_{10}^{+}, \mathrm{FeC}_{6} \mathrm{H}_{6}^{+}$, $\mathrm{FeC}_{5} \mathrm{H}_{5}^{+}, \mathrm{C}_{5} \mathrm{H}_{5}^{+-}$, and $\mathrm{Fe}^{+}$. The ionization (IP) and appearance potential (AP) measurements for the major ion ferrocene species are summarized in Table 1 . The ionization and appearance potential measurements for the major parent and fragment ions of 1, 1 -dichloroferrocene are summarized in Table II. The parent and fragment species identified in the mass spectrum from the equilibrium vaporization of $1,1^{\prime}, 2,2^{\prime}$-tetrachloroferrocene as well as the ionization and appearance potential measurements for the major ionic tetrachloroferrocene species are summarized in Table III.

The relative intensities of the parent and major ions observed in the mass spectrometer for ferrocene, $1,1^{\prime}$-dichloroferrocene, and 1, $\mathbf{3}^{\prime}, 2,2^{\prime}$-tetrachloroferrocene have been plotted as a function of electron impact energy in Fig. 1. These results are not as detailed as the IEC derived information but they do, as will be discussed later, provide some information as to the breakdown of these molecules in the mass spectrometer. 
TABI.E I. The appearance potentials from the ionization efficiency curves of the various ionic ferrocene species. Arrows designate relative increases ( $\uparrow$ ) and decreases $(1)$ of siope in the parent IEC's. Frevious measurements for the first appearance potentiais have also been included.

\begin{tabular}{|c|c|c|c|}
\hline Species & $\mathrm{AP}[\mathrm{eV}]$ & $\begin{array}{c}\text { Relative increase }(\uparrow) \\
\text { or decrease }(\downarrow) \\
\text { of slope in the parent of } I E C\end{array}$ & $m / e$ \\
\hline $\operatorname{Fe}\left(\mathrm{C}_{5} \mathrm{H}_{5}\right)_{2}^{+}$ & $\begin{array}{ll}6.9 \pm 0.2 & \\
6.47 \pm 0.009[6] \\
6.77 \pm 0.02 & {[7]} \\
6.9 \pm 0.1 & {[8]} \\
6.9 \pm 0.2 & {[9]} \\
7.05 \pm 0.1 & {[18]} \\
7.15 \pm 0.1 & {[20]} \\
8.3 & \\
9.4 & \\
12.1 & \\
13.0 & \end{array}$ & $\begin{array}{l}1 \\
1 \\
1 \\
1\end{array}$ & 185 \\
\hline $\mathrm{FeC}_{6} \mathrm{H}_{6}^{+}$ & $\cdots$ & & 134 \\
\hline $\mathrm{FeC}_{5} \mathrm{H}_{5}^{+}$ & $\begin{array}{lr}12.7 \pm 0.3 & \\
13.162 \pm 0.35 & {[6]} \\
13.93 \pm 0.08 & {[7]} \\
13.9 \pm 0.2 & {[9]} \\
14.38 \pm 0.3 & {[18]} \\
13.78 \pm 0.2 & {[19]}\end{array}$ & & 121 \\
\hline $\mathrm{Fe}^{+}$ & 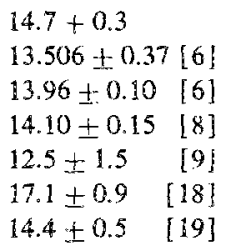 & & 56 \\
\hline
\end{tabular}

The photoionization mass spectrum of 1,1'-dichioroferrocene was studied between 10 and $24 \mathrm{eV}$ in steps of $l \mathrm{eV}$. The parent ion and the $\mathrm{C}_{10} \mathrm{H}_{8}{ }^{+}$fragment were the major ions observed. The $\mathrm{C}_{10} \mathrm{H}_{8}^{-1}$ ion intensity increases to a greater value than the parent ion intensity between 13 and $14 \mathrm{eV}$ incident photon energies as indicated in Fig. 2. When undispersed zero-order light is used for ionization, the parent and the $\mathrm{C}_{10} \mathrm{H}_{8}^{+}$fragment are formed in a ratio of $4.2: 1$ whereas the contribution of intensities found at $m / e=56,73-78,92$ 94, 99-102, 182, and 219 (see Table II) remain negligible $(<0.7 \%$ of the total ion current). Thus while the production of $\mathrm{C}_{10} \mathrm{H}_{8}^{+}$accounts for an appreciable percentage of the fragment formation in the electron impact mass spectrum (about $45 \%$ of the total ion current), in photoionization the formation of $\mathrm{C}_{10} \mathrm{H}_{8}^{+}$ion becomes almost exclusive.

\section{DISCUSSION}

On the basis of the electron impact ionization appearance potential data (Tables $\mathrm{I}-\mathrm{III}$ ) one can conclude that for $N=0$ and $N=1$ of $\mathrm{Fe}\left(\mathrm{C}_{5} \mathrm{H}_{5-N} \mathrm{Cl}_{N}\right)_{2}$ no fragments are formed by direct cleavage of iron to ring bonds by electron impact (EI) at energies smaller than $12.7 \mathrm{eV}$ for ferrocene and $14.5 \mathrm{eV}$ for $1^{1} 1^{\prime}$-dichloroferrocene. For $1,1^{\prime}, 2,2^{\prime}$-tetra-
TABLE II. The appearance potentials from the ionization efficiency curves of the various ionic dichloroferrocene species. Arrows designate relative increases ( 1 ) and decreases ( 1 ) of slope in the parent IEC's. * indicates that low intensities and pronounced "tailing" of the IEC make a choice between a lower and a higher AP value difficult.

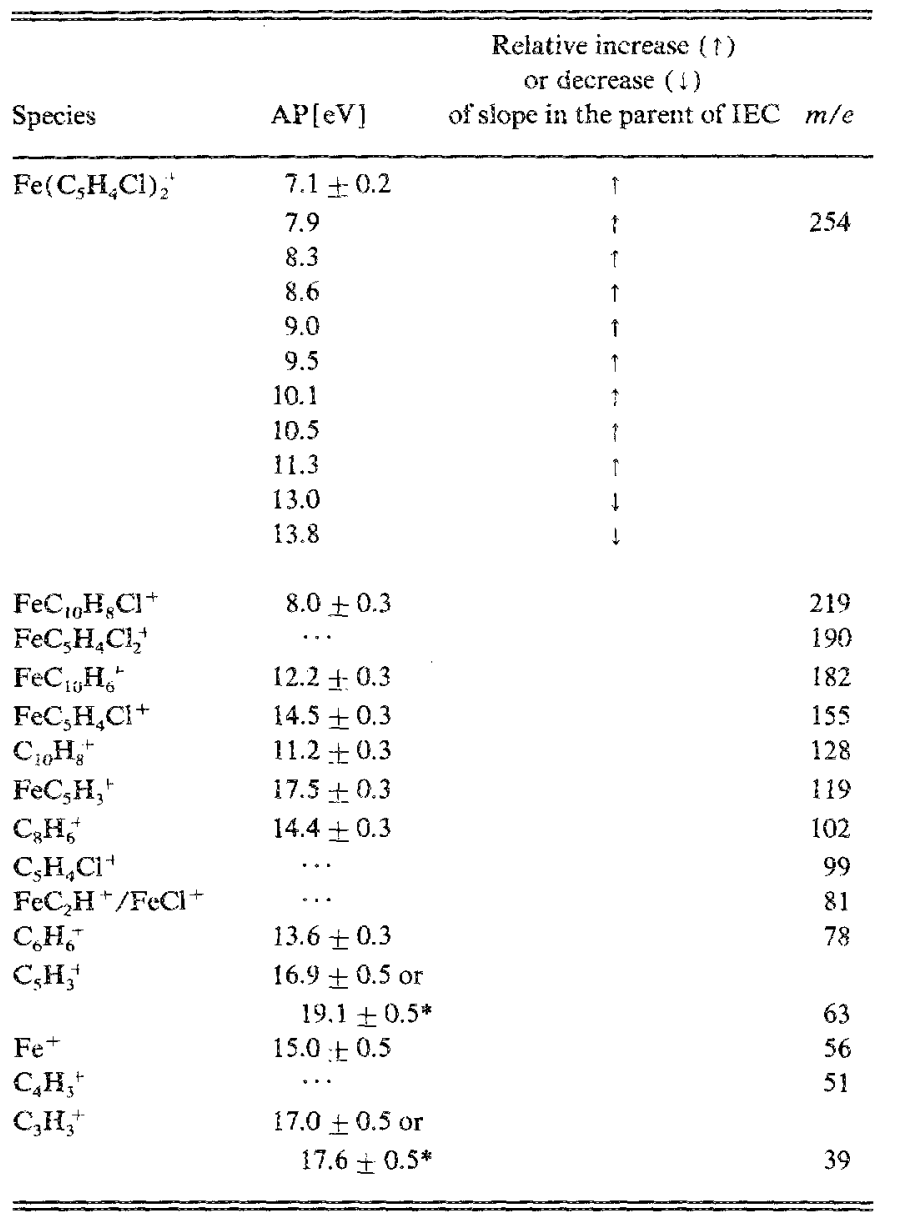

TABLE III. The appearance potentials from the ionization efficiency curves of various ionic tetrachloroferrocene species. Arrows designate relative increases $(\uparrow)$ and decreases $(\downarrow)$ of slope in the parent IEC's.

\begin{tabular}{|c|c|c|c|}
\hline Species & $\mathrm{AP}[\mathrm{eV}]$ & $\begin{array}{c}\text { Relative increase }(i) \\
\text { or decrease }(t) \\
\text { of slope in the parent of IEC }\end{array}$ & $m / e$ \\
\hline $\mathrm{Fe}\left(\mathrm{C}_{5} \mathrm{H}_{3} \mathrm{Cl}_{2}\right)_{2}{ }^{+}$ & $\begin{array}{l}7.3 \pm 0.2 \\
8.0 \\
8.5 \\
8.8 \\
9.5 \\
10.4 \\
11.4 \\
13.3\end{array}$ & $\begin{array}{l}\uparrow \\
\hat{\imath} \\
\uparrow \\
\uparrow \\
\downarrow \\
\downarrow \\
\downarrow \\
\uparrow\end{array}$ & 322 \\
\hline $\mathrm{FeC}_{10} \mathrm{H}_{6} \mathrm{Cl}_{3}{ }^{+}$ & $8.7 \pm 0.3$ & & 287 \\
\hline $\mathrm{C}_{10} \mathrm{H}_{6} \mathrm{Cl}_{2}^{+}$ & $11.8 \pm 0.3$ & & 196 \\
\hline $\mathrm{C}_{10} \mathrm{H}_{6} \mathrm{Cl}^{+}$ & $13.6 \pm 0.5$ & & 161 \\
\hline $\mathrm{C}_{5} \mathrm{H}_{3}^{+}$ & $17.0 \pm 0.5$ & & 63 \\
\hline
\end{tabular}




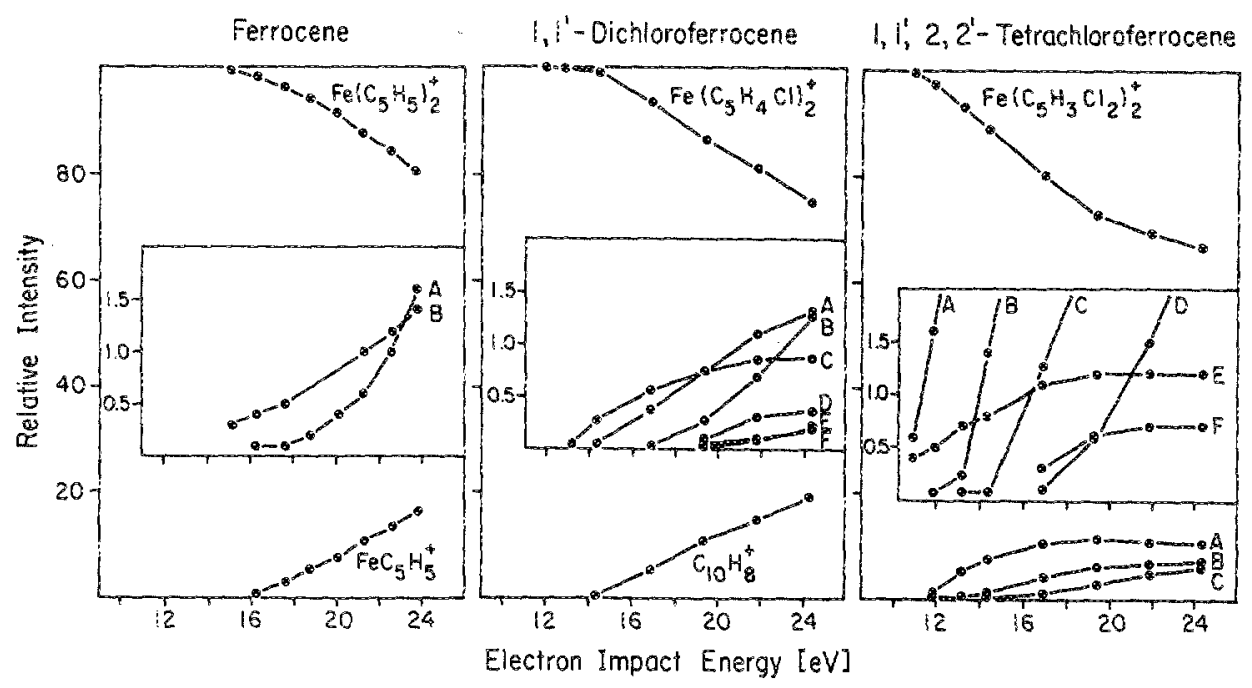

FiG. 1. The breakdown diagrams for ferrocene, dichloroferrocene, and tetrachloroferrocene derived from electron impact ionization efficiency curves. The relative intensities are plotred as function of electron impact energy. A relative intensity of 100 implies this is the only observed fragment. For ferrocene the parent ion, $\mathrm{FeC}_{5} \mathrm{H}_{5}{ }^{+}, \mathrm{FeC} \mathrm{C}_{6} \mathrm{H}_{6}^{+}(\mathrm{B})$, and $\mathrm{Fe}^{+}{ }^{+}$(A) relative intensities are shown. For dichtoroferrocene, the parent ion, $\mathrm{C}_{10} \mathrm{H}_{8}^{+}$, $\mathrm{C}_{8} \mathrm{H}_{6}^{+}(\mathrm{A}), \mathrm{C}_{3} \mathrm{H}_{3}^{+}(\mathrm{B}), \mathrm{FeC}_{\mathrm{i} 0} \mathrm{H}_{8}^{+}(\mathrm{C})$, $\mathrm{FeC}_{5} \mathrm{H}_{4} \mathrm{Cl}^{+}(\mathrm{D}), \mathrm{C}_{5} \mathrm{H}_{4}(\mathrm{E})$, and $\mathrm{Fe}^{+}(\mathrm{F})$ relative intensities are shown. For tetrachloroferrocene the parent ion, $\mathrm{C}_{10} \mathrm{H}_{6} \mathrm{Cl}_{2}^{+}(\mathrm{A}), \quad \mathrm{C}_{10} \mathrm{H}_{6} \mathrm{Cl}^{+}(\mathrm{B})$, $\mathrm{C}_{10} \mathrm{H}_{6}^{+}(\mathrm{C}), \mathrm{C}_{5} \mathrm{H}_{3}^{+}(\mathrm{D}), \mathrm{C}_{10} \mathrm{H}_{6} \mathrm{Cl}_{3}^{+}(\mathrm{E})$, and $\mathrm{FeC}_{5} \mathrm{H}_{3} \mathrm{Cl}^{+}(\mathrm{F})$ relative intensities have been plotted. chloroferrocene, the cleavage of iron to ring bonds by electron impact has not been observed. The preferential abstraction of chlorine (or $\mathrm{HCl}$ ) and $\mathrm{FeCl}_{2}$ from the parent ion at impact energies $E \leqslant 13.6 \mathrm{eV}$ for $1,1^{\prime}$-dichloroferrocene and $E \leqslant 12.2 \mathrm{eV}$ for $1,1^{\prime}, 2,2^{\prime}$-tetrachloroferrocene represent the energetically most favorable fragmentation pathways. At higher energies ( $\geqslant 14.5 \mathrm{eV}$ for 1,1'-dichloroferrocene) cleavage of iron to ring bonds and carbon-carbon bonds within the cyclopentadienyl rings become observable.

The probable fragmentation processes of the parent ferrocene, 1, $1^{\prime}$-dichloroferrocene and 1,1',2,2'-tetrachloroferrocene can be made by comparing the IEC's of the parent ions with the corresponding fragment appearance potentials. The results are summarized in Table IV.

For ferrocene, the decrease in the parent ion IEC slope at $13.0 \mathrm{eV}$ corresponds quite well with the appearance potential of $12.7 \mathrm{eV}$ for the $\mathrm{FeC}_{5} \mathrm{H}_{5}^{+}$ion. The 13.0-eV appearance potential for $\mathrm{FeC}_{5} \mathrm{H}_{5}^{+}$measured by electron impact is in good agreement with the value of $13.162 \pm 0.035 \mathrm{eV}$ acquired using photoionization. ${ }^{6}$ Other measurements for this

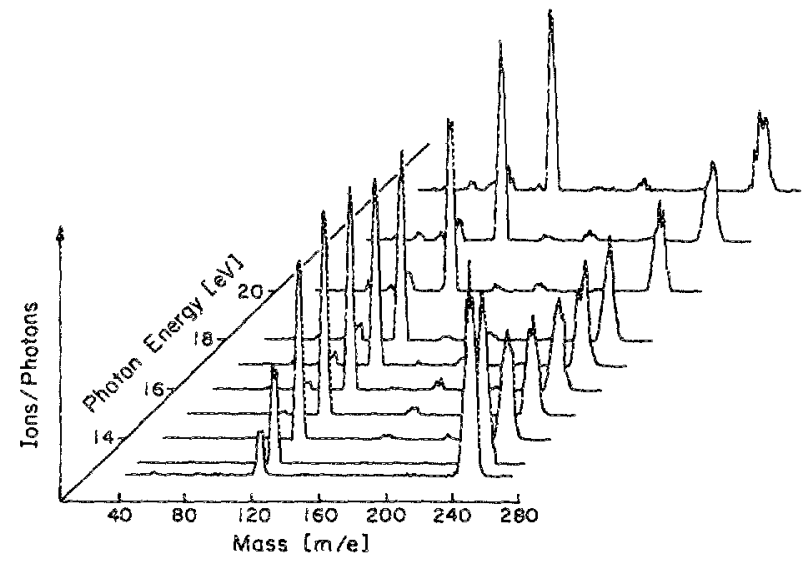

FiG. 2. The mass spectra of photon-induced ionization of $1,1^{\prime}$-dichloroferrocene for various photon energies. The photon energy source was the BESSY synchrotron light source. The dichloroferrocene was evolved from a Knudsen cell at a temperature of $305 \mathrm{~K}$. The ion count has been normalized to a constant photon flux. appearance potential (see Table I) have been observed at a higher value than our measured value of 12.7 to $13.0 \mathrm{eV}$. This discrepancy can be explained for previous electron inpact studies by the possibly large "taihing" of the earlier workers. As stated above, this strongly suggests direct cleavage of the iron-to-ring bonds. The bond dissociation energy of the metal-to-ring bonds for the ion $\mathrm{Fe}\left(\mathrm{C}_{5} \mathrm{H}_{5}\right)_{2}^{+}$must then be the ionization potential of ferrocene minus the appearance potential of $\mathrm{FeC}_{5} \mathrm{H}_{5}^{+}$[or corresponding higher appearance potential in the $\left.\mathrm{Fe}\left(\mathrm{C}_{5} \mathrm{H}_{5}\right)_{2}+\mathrm{IEC}\right]$. Thus

$$
\begin{aligned}
D\left(\mathrm{FeC}_{5} \mathrm{H}_{5}-\mathrm{C}_{5} \mathrm{H}_{5}\right)^{++}= & \operatorname{AP}\left(\mathrm{FeC}_{5} \mathrm{H}_{5}^{+}\right) \\
& -\operatorname{IP}\left[\mathrm{Fe}\left(\mathrm{C}_{5} \mathrm{H}_{5}\right)_{2}\right] \\
= & 13.0 \mathrm{eV}-6.9 \mathrm{eV}=6.1 \mathrm{eV} .
\end{aligned}
$$

This value for the $\mathrm{FeCp}_{2} \rightarrow \mathrm{FeCp}^{+}+\mathrm{Cp}$ process is somewhat smaller than a value estimated from some earlier electron impact measurements 7 to be between 7.2 and $7.5 \mathrm{eV}$. Nonetheless, more reliable photolonization measurements ${ }^{6}$ suggest that the ferrocene ion dissociation energy is approximately $6.5 \mathrm{eV}$ in reasonable agreement with our value of 6.1 $\mathrm{eV}$. The decomposition thermodynamic cycles can be constructed for ferrocene now by using data available in the literature and the ionic bond dissociation energy $D\left(\mathrm{FeC}_{5} \mathrm{H}_{5}-\mathrm{C}_{5} \mathrm{H}_{5}\right)^{+}=6.1 \mathrm{eV}$. This ionic species bond dissociation energy, the ionization potential of ferrocene of $6.9 \pm 0.2 \mathrm{eV}$ and the neutral bond dissociation energy $D\left(\mathrm{FeC}_{5} \mathrm{H}_{5}-\mathrm{C}_{5} \mathrm{H}_{5}\right)=3.96 \mathrm{eV}^{10}$ imply that the ionization potential of $\mathrm{FeC}_{5} \mathrm{H}_{5}$ is $9.04 \pm 0.5 \mathrm{eV}$ (as shown in Fig. 3). Using an ionization potential for $\mathrm{FeC}_{5} \mathrm{H}_{5}$ of $9.04 \mathrm{eV}$, an ionization potential for $\mathrm{Fe}$ of $7.87 \mathrm{eV}^{11}$ ard a neutral bond dissociation energy of $D\left(\mathrm{Fe}-\mathrm{C}_{5} \mathrm{H}_{5}\right)=2.21 \mathrm{eV}$, ${ }^{10}$ an ionic bond dissociation energy $D\left(\mathrm{Fe}-\mathrm{C}_{5} \mathrm{H}_{5}\right)^{+}=1.04 \pm 0.5 \mathrm{eV}$ is derived. From this we would expect an appearance potential for $\mathrm{Fe}^{+}$from the process $\mathrm{Fe}\left(\mathrm{C}_{5} \mathrm{H}_{5}\right)_{2} \rightarrow \mathrm{Fe}^{+}+2\left(\mathrm{C}_{5} \mathrm{H}_{5}\right)$ to have an energy of

$$
\begin{aligned}
& \operatorname{lP}\left[\mathrm{Fe}\left(\mathrm{C}_{5} \mathrm{H}_{5}\right)_{2}\right]+D\left(\mathrm{FeC}_{5} \mathrm{H}_{5}-\mathrm{C}_{5} \mathrm{H}_{5}\right)^{+} \\
& \quad+D\left(\mathrm{Fe}-\mathrm{C}_{5} \mathrm{H}_{5}\right)^{+}=6.9+6.1+1.0 \mathrm{eV} \\
& =14.0 \pm 0.5 \mathrm{eV} .
\end{aligned}
$$


TABLE IV. The fragmentation processes for ferrocene, 1,1'-dichloroferrocene, and 1,1'2,2'-tetrachloroferrocene ions are listed. The type of process suggested by the parent IEC slope change is indicated. The energies of fragmentation are indicated both by the fragment appearance potential and the appropriate higher appearance potential of the parent ion.

\begin{tabular}{|c|c|c|c|c|}
\hline & & Ionic frag & tation processes & \\
\hline & $\begin{array}{l}\text { Breaks in the } \\
\text { parent IEC [eV] }\end{array}$ & $\begin{array}{c}\text { Fragment AP } \\
{\left[\mathrm{eV}^{-}\right]}\end{array}$ & Fragment & $\begin{array}{l}\text { Probable } \\
\text { fragmentation }\end{array}$ \\
\hline $\mathrm{Fe}\left(\mathrm{C}_{5} \mathrm{H}_{5}\right)_{2}$ & $13.0(1)$ & 12.7 & $\mathrm{FeC}_{5} \mathrm{H}_{s}^{+}$ & Direct \\
\hline $\mathrm{Fe}\left(\mathrm{C}_{5} \mathrm{H}_{4} \mathrm{Cl}\right)_{2}$ & $13.6(\downarrow)$ & 13.8 & $\mathrm{C}_{6} \mathrm{H}_{6}{ }^{+}$ & Direct \\
\hline & $7.9(\uparrow)$ & 8.0 & $\mathrm{FeC}_{10} \mathrm{H}_{8} \mathrm{Cl}^{+}$ & $\begin{array}{l}\text { Predissociation } \\
\mathrm{Fe}\left(\mathrm{C}_{5} \mathrm{H}_{4} \mathrm{Cl}\right)_{2}^{+} \text {minus } \mathrm{Cl}\end{array}$ \\
\hline & $11.3(1)$ & 11.2 & $\mathrm{C}_{10} \mathrm{H}_{8}^{+}$ & Predissociation \\
\hline & & & & $\mathrm{Fe}\left(\mathrm{C}_{5} \mathrm{H}_{4} \mathrm{Cl}\right)_{2}{ }^{+}$minus $\mathrm{FeCl}_{2}$ \\
\hline $\mathrm{Fe}\left(\mathrm{C}_{5} \mathrm{H}_{3} \mathrm{Cl}_{2}\right)_{2}$ & $8.8(\uparrow)$ & 8.7 & $\mathrm{FeC}_{10} \mathrm{H}_{6} \mathrm{Cl}_{3}+$ & Predissociation \\
\hline & & & & $\mathrm{Fe}\left(\mathrm{C}_{5} \mathrm{H}_{3} \mathrm{Cl}_{2}\right)^{+}$minus $\mathrm{Cl}$ \\
\hline & $11.4(1)$ & 11.8 & $\mathrm{C}_{10} \mathrm{H}_{6} \mathrm{Cl}_{2}^{+}$ & $\begin{array}{l}\text { Direct } \\
\mathrm{Fe}\left(\mathrm{C}_{5} \mathrm{H}_{3} \mathrm{Cl}_{2}\right)_{2}^{+} \text {minus } \mathrm{FeCl}_{2}\end{array}$ \\
\hline & $13.3(1)$ & 13.6 & $\mathrm{C}_{10} \mathrm{H}_{6} \mathrm{Cl}^{+}$ & $\begin{array}{l}\text { Predissociation } \\
\mathrm{Fe}\left(\mathrm{C}_{5} \mathrm{H}_{3} \mathrm{Cl}_{2}\right)_{2}^{+} \text {minus } \\
\mathrm{FeCl}_{2} \text { and } \mathrm{Cl}\end{array}$ \\
\hline
\end{tabular}

This value of $14.0 \pm 0.5 \mathrm{eV}$ is in moderate agreement with the observed appearance potential $\mathrm{Fe}^{+}$at $14.7 \pm 0.5 \mathrm{eV}$. A number of previous studies ${ }^{6-8,19}$ have values for the appearance potential of $\mathrm{Fe}^{+}$from the decomposition of the ferrocene ion close to a value of $14.0 \mathrm{eV}$ consistent with our thermodynamic cycle.

For 1,1'-dichloroferrocene and 1,1',2,2'-tetrachloroferrocene, the metal-to-ring cleavage favors $\mathrm{CpCl}^{+}$and $\mathrm{CpCl}_{2}^{+}$ ion formation, respectively, rather than the formation of a $\mathrm{FeC}_{5} \mathrm{H}_{5-N} \mathrm{Cl}_{N}^{+}$ion. For $1,1^{\prime}$-dichloroferrocene we may estimate the ionic bond dissociation energy

$$
\begin{aligned}
D & \left(\mathrm{FeC}_{5} \mathrm{H}_{4} \mathrm{Cl}-\mathrm{C}_{5} \mathrm{H}_{4} \mathrm{Cl}\right)^{+} \\
& =\mathrm{AP}\left(\mathrm{FeC}_{5} \mathrm{H}_{4}^{+}\right)-\mathrm{IP}\left[\mathrm{Fe}\left(\mathrm{C}_{5} \mathrm{H}_{4} \mathrm{Cl}\right)_{2}\right] \\
& =14.5-7.1 \mathrm{eV} \\
& =7.4 \mathrm{eV} .
\end{aligned}
$$

This is greater than the comparabie ionic dissociation of ferrocene at $6.1 \mathrm{eV}$. This indicates that chlorination does increase the metal-to-ring bond strength for the chloroferrocene ion.

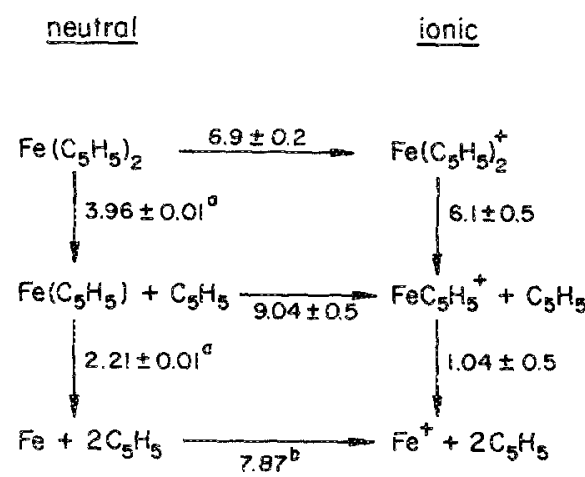

FrG. 3. The decomposition thermodynamic cycles for neutral and ionic ferrocene. All numbers are in units of $\mathrm{eV}$.
The increasing appearance potentials for abstraction of $\mathrm{FeCl}_{2}, \mathrm{Cl}$, or $\mathrm{HCl}$ from $1,1^{\prime}$-dichloroferrocene to $1,1^{\prime}, 2,2^{\prime}$ tetrachloroferrocene are another indication that successive chlorination leads to increasing stability for the chloroferrocene ions.

With photoionization almost all the fragmentation occurs via $\mathrm{FeCl}_{2}$ elimination. Since elimination reactions appear to dominate photoionization to a greater extent than occurs for electron impact, there may exist a photoexcited intermediate step to dissociation with a large cross section in the region of 13 to $14 \mathrm{eV}$.

The ionization potentials measured by electron impact for ferrocene and $1,1^{\circ}$-dichloroferrocene are in good agreement with earlier photoemission experiments ${ }^{8,12-17}$ as detailed elsewhere. ${ }^{3}$ Some previous studies ${ }^{20,21}$ have observed attachment of a cyclopentadienyl ring to ferrocene in the mass spectrometer to form $\mathrm{FeCp}_{3}{ }^{+}$. This species is unimportant in the decomposition thermodynamics of ferrocene.

\section{CONCLUSION}

We have constructed the thermodynamic cycles indicating the fragmentation energies for ferrocene. Chlorination of ferrocene results in increasing stability of the ion with respect to metal-to-ring cleavage. Elimination reactions for the chlorinated ferrocene ions are an important fragmentation process. This suggests that plasma assisted deposition of iron using chlorinated ferrocenes will certainly result in chlorine contamination of the film.

\section{ACKNOWLEDGMENTS}

This work was supported by the Bundesministerium fïr Forschung und Technoiogie and Syracuse University through a grant given to $\mathrm{DCD}$.

\footnotetext{
"Present address: Siemens, AG, UB Med, Henkestrasse 127, 8520 Erlangen, Federal Republic of Germany.

b) Present address: Department of Chemistry and Applied Chemistry, Saí-
} 
ford University, Salford, England, M5-4WT.

${ }^{1}$ M. Inoue, K. Itoh, and K. Asahi, U.S. Patent No. 4193835 (18 March 1980); G. Stauf, D. C. Driscol, P. A. Dowben, S. Bartuss, and M. Grade in Proceedings of the International Conference on Metallurgical Coatings, San Diego, 1987; Y. A. Kaplan, L. S. Chernysh, M. M. Chesnoki, N. M. Protasov, Ivz. Chine. K. 27, 43 (1984).

2D. C. Driscoll, J. A. Bishop, B. J. Sturm, P. A. Dowben, and C. G. Olsen, J. Vac. Sci. Technoi. A 4, 823 (1986).

${ }^{3}$ D. C. Driscoll, P. A. Dowben, N. M. Boag, M. Grade, and S. Barfuss, J. Chem. Phys. 85, 4802 (1986).

${ }^{4}$ M. Grade, J. Wienecke, W. Rosinger, and W. Hirschwald, Ber. Bunsenges. Phys. Chem. 87, 355 (1983).

${ }^{5} W$. Rosinger, $M$. Grade, and W. Hirschwald, Ber. Bunsenges. Phys. Chem. 87, $536(1983)$.

${ }^{6}$ R. Bär, Th. Heinis, Ch. Nager, and M. Jungen, Chem. Phys. Lett. 91, 440 (1982).

${ }^{7}$ G. D. Flesch, G. A. Junk, and H. J. Svec, J. Chem. Soc. Dalton Trans. II, $1102(1972)$.

8. P. Puttemans and A. Hanson, Ing. Chim. 53, 17 (1971).
${ }^{9}$ G. M. Begun and R. N. Compton, J. Chem. Phys. 58, $227 \mathrm{i}$ (1973).

${ }^{10}$ K. E. Lewis and G. P. Sinith, J. Am. Chem. Soc. 106, 4650 (1984).

"Hardbook of Chemistry and Physics (CRC, Boca Raton, FL, 1980).

${ }^{12}$ S. Evans, M. E. H. Green, B. Jewitt, A. F. Orchard, and C. F. Pygall, J. Chem. Soc. Faraday Trans. II 68, 1185 (1972).

${ }^{13}$ J. W. Rabelais, L. O. Werme, T. Bergmark, L. Karlsson, M. Hussain, and K. Siegbahn, J. Chem. Phys. 57, 1185 (1972).

${ }^{14} \mathrm{~T}$. Vondrak, J. Organometal. Chem. 275, 93 (1984)

${ }^{15}$ S. Evans, M. L. H. Green, B. Jewit, G. H. King, and A. F. Orchard, $J$. Chem. Sos. Faraday Trans. II 70, 356 (1974).

${ }^{16} \mathrm{~J}$. C. Green, Structupe and Bonding (Springer, Berlin, 1981) Vol. 43, p. 37.

${ }^{17}$ C. Cauletti, J. C. Green, M. R. Kelly, P. Powell, J. van Tilborg, J. Robbins, and J. Smart, J. Electron Spectrosc. Relat. Pherom. 19, 327 (1980).

${ }^{18}$ L. Friedman, A. P. Irsa, and G. Wilkinson, J. Am. Chem. Soc. 77, 3689 (1955).

"J. Müller and L. D'or, J. Organometal. Chem. 10, 313 (1967).

${ }^{20} \mathrm{E}$. Schumacher and $R$. Taubenest, Helv. Chim. Acta 47, 1525 (1964).

${ }^{2 !}$ S. M. Shiderout, J. Am. Chent. Soc. 95, 3846 (1973). 